Numbers (percentages) of men and women in top 10 male and female dominated healthcare occupations for age range 18-44 years, 1971 and 2001

\begin{tabular}{|c|c|c|c|}
\hline & \multicolumn{2}{|c|}{ No/total of men and women (\%)) } & \multirow{2}{*}{$\begin{array}{c}\text { Change } \\
(\% \text { points })^{*}\end{array}$} \\
\hline & 1971 & 2001 & \\
\hline \multicolumn{4}{|l|}{ Male dominated } \\
\hline Orthotist & $50 / 50(100)$ & $54 / 87(62)$ & -38 \\
\hline Ambulance officer & $156 / 156(100)$ & $363 / 600(61)$ & -40 \\
\hline Hospital orderly & $551 / 559$ (99) & $375 / 534(70)$ & -28 \\
\hline Surgeon & 121/123 (98) & $237 / 270(88)$ & -11 \\
\hline Dentist/dental surgeon & 480/492 (98) & $480 / 786(61)$ & -37 \\
\hline Osteopath/chiropractor & $49 / 50(98)$ & 153/276 (55) & -43 \\
\hline Optometrist/dispensing optician & 108/111 (97) & $183 / 525(35)$ & -62 \\
\hline Physician & $82 / 88(93)$ & $396 / 639(62)$ & -31 \\
\hline General practitioner & $564 / 604(93)$ & $1134 / 2148(53)$ & -41 \\
\hline Gynaecologist/obstetrician & $27 / 30(90)$ & $21 / 60(35)$ & -55 \\
\hline \multicolumn{4}{|l|}{ Female dominated } \\
\hline Dental therapist & $1645 / 1645(100)$ & $390 / 399(98)$ & -2 \\
\hline Dietician/nutritionist & $117 / 117(100)$ & $231 / 255(91)$ & -9 \\
\hline Karitane nurse & $504 / 504(100)$ & $45 / 45(100)$ & 0 \\
\hline Midwife & $253 / 253(100)$ & $1116 / 1122(99)$ & -1 \\
\hline Plunket nurseł & $80 / 80(100)$ & $249 / 249(100)$ & 0 \\
\hline Public health nurse & 290/292 (99) & 489/501 (98) & -2 \\
\hline Occupational therapist & $246 / 248(99)$ & $1083 / 1209(90)$ & -10 \\
\hline Principal nurse & $80 / 81$ (99) & 177/198 (89) & -9 \\
\hline Registered nurse & $4806 / 4880$ (98) & 13968/14991 (93) & -5 \\
\hline Nurse aide & $3538 / 3603$ (98) & $3867 / 4140(93)$ & -5 \\
\hline
\end{tabular}

Percentage values do not always add to $100 \%$ owing to rounding.

*The decrease for each of the 10 male dominated occupations was highly significant $\left(\chi^{2}\right.$ test, $\left.P<0.0001\right)$. †Nurse trained in the care of young babies and their mothers, according to the principles of the Plunket Society (a major provider of well child and family health services in New Zealand). fNurse who works for the Plunket Society.

dominated occupations showed a highly significant decrease $\left(\chi^{2}\right.$ test, $\left.\mathrm{P}<0.0001\right)$ in the proportion of men in 2001 compared with 1971. The decrease ranged from 11 percentage points in surgeons to 62 percentage points in optometrists/dispensing opticians. Regardless of length of training or level of skill needed, none of these 10 occupations was male dominated in 2001. Moreover, in two occupations (optometrist/ dispensing optician and obstetrician/gynaecologist) women became the majority.

In contrast, eight of the top 10 female dominated occupations remained female dominated in 2001. The two that did not (occupational therapist and principal nurse) dipped only slightly below the category definition, with female proportions of $89.6 \%$ and $89.4 \%$ respectively. The decrease in the proportion of women in the top 10 female dominated occupations ranged from 0 to 10 percentage points. Two of the female dominated occupations showed no change in 2001 compared with 1971; both occupations were entirely female in both years.

For some occupations, the numbers in the workforce rose substantially. These increases are partly explained by a $36 \%$ rise in New Zealand's population, a change in definition of some jobs, and a rise in the number of part time general practitioners.

\section{Comment}

For workers aged 19-44, healthcare occupations that were male dominated 30 years ago are now balanced for the sexes, whereas occupations that used to be female dominated continue to be so. Our results therefore support the prediction that equal opportunities legislation would widen the choices for women. The same is not true for men, however, as women have retained their big majorities in the female dominated occupations; very few men have entered these occupations.

The reliability of these results is probably high. The data are from a small, developed country that has good quality census data. The extent to which these results might be atypical is unknown, although published results from other developed countries show a similar trend.

Contributors: VJG conceived the idea and wrote the paper, ER did the statistical analysis, and PM collected and researched the data. VJG will act as guarantor.

Funding: No special funding.

Competing interest: None declared.

Ethical approval: Not needed.

1 De Beauvoir S. The second sex. London:Jonathan Cape, 1953.

2 New Zealand Statistics. Welllington: New Zealand Government Publications, 1971 .

Wootton BH. Gender differences in occupational employment Monthly Labor Review 1997;120:15-24.

(Accepted 8 December 2003)
Academic Department of Obstetrics and Gynaecology, Faculty of Medicine Imperial College, London W2 1NY

Jenny Higham senior lecturer continued over BMJ 2004;328:142-3

\title{
Gender gap in undergraduate experience and performance in obstetrics and gynaecology: analysis of clinical experience logs
}

\author{
Jenny Higham, Philip J Steer
}

The percentage of UK graduates considering a career in obstetrics and gynaecology is falling. ${ }^{1}$ In 1974 , for example, $3.9 \%$ of men (55) and $4.3 \%$ of women (23) specified the specialty as their first preference for a career'; by 2000 , this was only $0.9 \%(12)$ and $3.2 \%(54) .{ }^{1}$ An increasing proportion of women in the workforce exacerbates the shortage, as overall women contribute fewer working hours than men to the specialty. ${ }^{3}$ Experiences during undergraduate training are likely to influence graduates' perceptions of identifying with and thriving within a given specialty. Differences in experience and performance in examinations may explain, at least in part, the current reluctance of male students to consider a career in obstetrics and gynaecology.

\section{Participants, methods, and results}

All undergraduates have completed a detailed log of clinical experience since 1997. By sex, we analysed 
Clinical experience and performance in examinations for obstetrics and gynaecology among medical students, analysed by $\operatorname{sex}^{\star}$

\begin{tabular}{|c|c|c|c|c|c|}
\hline & $\begin{array}{l}\text { Total No } \\
\text { students }\end{array}$ & Mean & Median & 5th centile & $\begin{array}{l}\text { 95th } \\
\text { centile }\end{array}$ \\
\hline \multicolumn{6}{|l|}{ Experience } \\
\hline \multicolumn{6}{|c|}{ No of normal deliveries performed: } \\
\hline Men & 521 & 2.74 & 3.00 & 0.00 & 5.25 \\
\hline Women & 505 & 3.17 & 3.00 & 0.22 & 6.00 \\
\hline \multicolumn{6}{|c|}{ No of normal deliveries seen: } \\
\hline Men & 521 & 3.33 & 3.00 & 1.00 & 8.00 \\
\hline Women & 505 & 3.91 & 3.00 & 1.22 & 8.00 \\
\hline \multicolumn{6}{|c|}{$\begin{array}{l}\text { No of caesarean sections } \\
\text { scrubbed for: }\end{array}$} \\
\hline Men & 521 & 4.01 & 4.00 & 1.00 & 8.25 \\
\hline Women & 505 & 3.70 & 3.00 & 1.00 & 8.00 \\
\hline \multicolumn{6}{|c|}{ No of cuscoes speculum examinations: } \\
\hline Men & 521 & 4.27 & 4.00 & 2.00 & 8.25 \\
\hline Women & 505 & 5.32 & 5.00 & 2.00 & 10.00 \\
\hline
\end{tabular}

\section{No of bimanual pelvic}

examinations:

\begin{tabular}{|c|c|c|c|c|c|}
\hline Men & 521 & 6.01 & 5.00 & 1.08 & 14.00 \\
\hline Women & 505 & 6.94 & 6.00 & 2.00 & 15.00 \\
\hline \multicolumn{6}{|c|}{ No of cervical smears taken: } \\
\hline Men & 521 & 1.84 & 1.17 & 1.00 & 4.00 \\
\hline Women & 505 & 2.30 & 2.00 & 1.00 & 5.00 \\
\hline
\end{tabular}

Examination results

Obstetrics presentationt:

\begin{tabular}{|c|c|c|c|c|c|}
\hline Men & 259 & 8.30 & 8.00 & 6.00 & 10.00 \\
\hline Women & 239 & 8.73 & 9.00 & 7.00 & 10.00 \\
\hline \multicolumn{6}{|c|}{ Gynaecology presentationt: } \\
\hline Men & 259 & 8.20 & 8.00 & 6.00 & 10.00 \\
\hline Women & 239 & 8.64 & 9.00 & 7.00 & 10.00 \\
\hline \multicolumn{6}{|c|}{ Multiple true or false examł: } \\
\hline Men & 400 & 48.79 & 50.00 & 40.00 & 60.00 \\
\hline Women & 373 & 50.55 & 50.00 & 40.00 & 60.00 \\
\hline
\end{tabular}

Objective structured clinical

exam§:

\begin{tabular}{llllll}
\hline Men & 400 & 108.59 & 109.00 & 95.00 & 121.00 \\
\hline Women & 373 & 112.21 & 113.00 & 97.00 & 124.00
\end{tabular}

${ }^{*}$ All differences between sex are significant to $\mathrm{P}<0.001$ (Mann-Whitney $\mathrm{U}$ test) except caesarean sections scrubbed for $(\mathrm{P}=0.04)$.

†For 498 students before a recent change in the format of marking. tMarked from 40 to 60 .

$\$ 14$ stations of six minutes each; maximum mark 10 for each station. Data for 773 students after end of attachment exams became finals in 2000 .

recorded experience and performance in examinations (two case presentations, a multiple true or false paper, and an objective structured clinical examination) for 1036 consecutive students (529 men and 507 women). Men and women had done similar numbers of clerkings.

Men had significantly less clinical experience in obstetrics and in gynaecology, except in relation to scrubbing for caesarean sections (table). Women did significantly better in all aspects of assessment. Nine men failed compared with three women, although this was not significant (Fisher's exact test $\mathrm{P}=0.145$ ). Eight men were awarded distinctions, compared with 26 women, which was highly significant (Fisher's exact test $\mathrm{P}=0.0014)$.

\section{Comment}

Male students have significantly less clinical experience than female students in key areas of obstetrics and gynaecology, such as passing a speculum and taking a cervical smear. Men also perform less well in examinations. These significant differences between the sexes are perhaps not unexpected, but we were surprised by the magnitude of some of them.
We now use mannekins for testing competency at passing a speculum and taking cervical smears in our final examination, to ensure basic competency. Anecdotally, our male students report increasing numbers of women declining to have male students involved in their care, often reflecting cultural issues. In addition, male students report that some midwives are less helpful than they are to female students.

Differences in clinical experience according to sex have been reported in the United States, with women students receiving more experience in seven of 12 skills specific to women and men receiving more experience in two of three skills specific to men. Greatest experience was gained where teacher, student, and patients were of the same sex.

Traditionally women are discriminated against in medical training; however, men are increasingly excluded from certain opportunities. Students of both sexes have voiced discomfort about what has been perceived as an anti-male environment in obstetrics and gynaecology. This unwelcoming attitude towards men is also a reason for men to reject careers in obstetrics and gynaecology. ${ }^{5}$ We must always respect patient autonomy, but we try to balance this by asking teachers to ensure men feel welcome and wanted.

Continuing to fail to recruit men to obstetrics and gynaecology will halve the pool of potential recruits while, allowing for career breaks, it will increase the number required. Additionally, negative undergraduate experiences may discourage men from involvement in contraception, well woman screening, and gynaecological problems in family practice. Excluding men from important aspects of reproduction is fundamentally unwise; the lack of adequate male role models is already widely cited as a problem afflicting society as a whole.

Contributors: Both authors conceived and designed the study, collected and analysed the data, and wrote the paper. Both authors are guarators.

Funding: None.

Competing interests: None declared.

Ethical approval: Not needed.

1 Lambert TW, Goldacre MJ, Turner G. Career choices of United Kingdom medical graduates of 1999 and 2000: questionnaire surveys. BMJ 2003:326:194-5.

2 Lambert TW, Goldacre MJ, Edwards C, Parkhouse J. Career preferences of doctors who qualified in the United Kingdom in 1993 compared with those of doctors qualifying in 1974, 1977, 1980, and 1983. BMJ $1996 ; 313: 19-24$

3 Pearse WH, Haffner WH, Primack A. Effect of gender on the obstetric-gynecologic work force. Obstet Gynecol 2001;97:794-7.

4 Nora LM, McLaughlin MA, Fosson SE, Stratton TD, Murphy-Spencer A, Fincher RM, et al. Gender discrimination and sexual harassment in medical education: perspectives gained by a 14-school study. Acad Med 2002;77:1226-34.

5 Lambert TW, Davidson JM, Evans J, Goldacre MJ. Doctor's reasons for rejecting initial choices of specialties as long-term careers. Med Edu 2003:37:312-8.

(Accepted 5 August 2003)

\section{Endpiece}

\section{Only one good}

There is only one good, knowledge, and one evil, ignorance. Socrates, 470-399 вс

Zameer Shah, research fellow, London
Chelsea and Westminster Hospital Campus Faculty of Medicine Imperial College

Philip J Steer professor

Correspondence to: J Higham j.higham@ imperial.ac.uk 